OPEN ACCESS

Edited by:

Mehdi Razzaghi-Abyaneh,

Pasteur Institute of Iran, Iran

Reviewed by:

Atte Von Wright,

University of Eastern Finland, Finland

Theo Varzakas,

Technological Educational Institute

of Peloponnese, Greece

*Correspondence: Bey-Hing Goh

goh.bey.hing@monash.edu;

Learn-Han Lee

lee.learn.han@monash.edu;

leelearnhan@yahoo.com

Specialty section:

This article was submitted to

Food Microbiology,

a section of the journal

Frontiers in Microbiology

Received: 23 November 2015

Accepted: 18 January 2016

Published: 05 February 2016

Citation:

Tan LT-H, Chan K-G, Lee L-H and Goh B-H (2016) Streptomyces

Bacteria as Potential Probiotics in Aquaculture. Front. Microbiol. 7:79. doi: 10.3389/fmicb.2016.00079

\section{Streptomyces Bacteria as Potential Probiotics in Aquaculture}

\author{
Loh Teng-Hern Tan', Kok-Gan Chan', Learn-Han Lee ${ }^{1 *}$ and Bey-Hing Goh ${ }^{1 *}$ \\ ${ }^{1}$ Biomedical Research Laboratory, Jeffrey Cheah School of Medicine and Health Sciences, Monash University Malaysia, \\ Bandar Sunway, Malaysia, ${ }^{2}$ Division of Genetics and Molecular Biology, Institute of Biological Sciences, Faculty of Science, \\ University of Malaya, Kuala Lumpur, Malaysia
}

In response to the increased seafood demand from the ever-going human population, aquaculture has become the fastest growing animal food-producing sector. However, the indiscriminate use of antibiotics as a biological control agents for fish pathogens has led to the emergence of antibiotic resistance bacteria. Probiotics are defined as living microbial supplement that exert beneficial effects on hosts as well as improvement of environmental parameters. Probiotics have been proven to be effective in improving the growth, survival and health status of the aquatic livestock. This review aims to highlight the genus Streptomyces can be a good candidate for probiotics in aquaculture. Studies showed that the feed supplemented with Streptomyces could protect fish and shrimp from pathogens as well as increase the growth of the aquatic organisms. Furthermore, the limitations of Streptomyces as probiotics in aquaculture is also highlighted and solutions are discussed to these limitations.

\section{Keywords: Streptomyces, probiotic, aquaculture, fish pathogens, antibiotic resistance}

\section{INTRODUCTION}

Statistics have revealed that the global aquaculture production continue to increase rapidly without the sign of reaching its peak. Meanwhile, the production from global capture fisheries has stabilized around 90 million tons since the mid-nineties (Mathieson, 2012). According to the United Nations Food and Agriculture Organization report (FAO, 2014), the global aquaculture production achieved another all-time high of 90.4 million tons including the 66.6 million tons of food fish and 23.8 million tons of aquatic algae in 2012 in response to the rising domestic and international seafood demand. Currently, it has been reported that food fish provides an average of one-fifth of total animal protein intake for the world population estimated at 7.3 billion people (Moffitt and Cajas-Cano, 2014). However, major disease outbreaks have been reported within the aquaculture sector in many part of the world due to the increased fish stocking density, overcrowding and lack of sanitary management with the rapid growth of aquaculture. The rapid spread of infections have led to global estimate of disease losses ranges about a quarter billion US\$ annually (Bondad-Reantaso et al., 2005). For instance, the viral infections (white-spot syndromes, yellow head disease and taura syndrome) in shrimp industry has cost billions of dollars worldwide (Flegel, 2012; Lightner et al., 2012). Also, bacterial pathogens such as Vibrio sp. (Vibrio harveyi, V. parahaemolyticus, V. campbellii) caused luminous vibriosis in shrimp farms resulted in 50-100\% mortality and vibrio infections in human (Shruti, 2012; Letchumanan et al., 2014; Wang et al., 2015).

Ever since the discovery of penicillin by Fleming in 1928 (Fleming, 1944), antibiotics have played unparalleled roles in disease prevention and treatment for human and animal 
health and welfare. In addition to the use in human medicine, antibiotics are widely utilized in food animals and aquaculture either as prophylactic or for growth enhancement (Marshall and Levy, 2011). Therefore, antibiotics are extensively used to ensure the development of the intensive and large-scale aquaculture industry. However, the uncontrolled and indiscriminate use of antibiotics has given rise to the emergence of antibiotic resistant bacteria in the aquaculture (Huang et al., 2015; Letchumanan et al., 2015a,b,c) and aquaculture ponds also have been evidenced as reservoirs for antibiotic resistance genes (Tomova et al., 2015; Xiong et al., 2015). These antibiotic resistance genes can be acquired by human and animal pathogens via horizontal gene transfer (Tomova et al., 2015), hence leading to difficulty in the treatment of infectious diseases. Moreover, the recent evidences of residual antibiotics in the cultured organisms could pose a potential health risk to human consumers (Chen et al., 2015; Pereira et al., 2015; Pham et al., 2015).

In order to overcome the continuous emergence of antibiotic resistance pathogens due to abuse of antibiotics in aquaculture, an alternative to antibiotics is urgently needed for disease prevention and treatment and also improvement of quality and sustainability of aquaculture production. Extensive reviews have done indicating that probiotics could be a promising alternative for antibiotics in aquaculture, demonstrating beneficial effects to host by combating diseases, improving growth and also stimulating immune responses of host toward infections (NewajFyzul et al., 2014; Hai, 2015). Therefore, the aim of this review is to provide an insight on the use of the genus Streptomyces bacteria as an alternative to antibiotics, being a probiotic in controlling diseases and improving the health and quality of aquaculture production. Furthermore, this review also discusses the prospects and limitations of Streptomyces species as a probiotic in aquaculture.

\section{PROBIOTICS}

The term 'probiotic' was initially defined as 'organisms and substances which contribute to intestinal microbial balance' (Parker, 1974). It was then revised as live microbial feed supplement which beneficially affects the host animal by improving its intestinal microbial balance' (Fuller, 1989). Meanwhile, in the case of aquatic animals which have much closer interactions with the external environment as compared to the terrestrial organisms, the external environment and feeding have substantial impacts on the microbial status of the aquatic animals. Hence, Verschuere et al. (2000) suggested that a probiotic for aquatic environments should be known as a live microbial adjunct exhibiting beneficial effect on the host by modulating the host-associated or ambient microbial community. Lately, probiotic was described as live, dead or component of a microbial cell that exerts beneficial effect on host by improving disease resistance, growth performance, feed utilization and health status, through the achievement of microbial balance in both host and ambient environments (Hai, 2015). Literatures have showed the possible mode of action of probiotics in aquaculture include (i) growth promoter, (ii) production of inhibitory compounds, (iii) improvement in nutrient digestion, (iv) water quality improvement, (v) enhancement of immune response, and (vi) competition for nutrient (Defoirdt et al., 2007; Martínez Cruz et al., 2012). In order to achieve a probiotic status, the microbes have to fulfill a number of criteria in term of their biosafety and functionality. The desirable characteristics of a potential probiotic include; (i) not harmful toward the host; (ii) ability to survive during transport to the active site; (iii) capability of colonizing and proliferating within the host; (iv) no virulence genes or antibiotic resistance genes (Hai, 2015). The common microorganisms used as probiotics are Lactobacillus acidophilus, Lactobacillus casei, Bacillus sp., Bifidobacterium bifidum, Lactococcus lactis and also the yeast, Saccharomyces cerevisiae (Ouwehand et al., 2002; Salamoura et al., 2014). However, less attention has been put on the use of Actinobacteria as probiotics in aquaculture despite being widely known as prolific producer for secondary metabolites, particularly the genus (Butler, 2008). The genus Streptomyces demonstrated promising results as probiotics (Das et al., 2010; Augustine et al., 2015). This review aim to discuss the prospects of using Streptomyces as a probiotic candidate in aquaculture. Table 1 summarizes all the features and mechanism of actions of the probiotic effects evidenced in the genus Streptomyces.

\section{STREPTOMYCES SP. AS PROBIOTICS IN AQUACULTURE}

The genus Streptomyces (phylum: Actinobacteria) are Grampositive, high G + C (70\%) genome content, soil-living bacteria with characterized branching filamentous morphology. Streptomyces sp. has been widely recognized as industrially important microorganism due to its potential in producing diverse range of secondary metabolites (Lee et al., 2014b; Ser et al., 2015a,b; Tan et al., 2015) including antibiotics (Lee et al., 2014a), antitumor agents, antiparasitic, immunosuppressive agents, and enzymes (Manivasagan et al., 2013). The production of a variety of wide-spectrum chemical compounds as demonstrated by Streptomyces has the advantage of producing potential antagonistic and antimicrobial compounds that can be valuable as probiotics in aquaculture. The ability of producing antagonistic compounds may help the probiotics to compete for nutrients and attachment sites in the host. For instance, the production of bacteriocins (Desriac et al., 2010), siderophores (Lalloo et al., 2010), enzymes (protease, amylase, lipase; Augustine et al., 2015), hydrogen peroxide (Sugita et al., 2007) and organic acids (Sugita et al., 1997) have been documented from the probiotics used in aquaculture. You et al. (2005) reported a Streptomyces sp. with siderophores producing activities and suggested that the use of this Streptomyces sp. can influence the growth of pathogenic Vibrio sp. by competition for iron in the aquatic environment. Siderophores are ferric ion-specific chelating agents with low molecular masses that are usually produced by microorganisms and plants under $\mathrm{Fe}$ limiting conditions (Ahmed and Holmstrom, 2014). Probiotics with the capability of producing siderophores are believed to outcompete the pathogens by limiting the bioavailability of iron 
TABLE 1 | The probiotic effects demonstrated by Streptomyces bacteria through different mechanism of actions.

Features/Mechanism Probiotic Streptomyces bacteria Outcomes
of actions

Antagonistic compounds production

- Siderophore production
Streptomyces cinerogriseus A03 and A05

Streptomyces griseorubroviolaceus

A26 and A42

Streptomyces lavendulae A41

Streptomyces roseosporus A45

Streptomyces griseofuscus B15

Streptomyces albus A66

Anti-biofilm and

anti-quorum

sensing activity
- Anti-virulence activity

Streptomyces sp. K01-0509

- Anti-viral activity

Streptomyces sp. AJ8
- All the strains positive for siderophore production, detected using CAS-agar

- Displayed antagonistic activity toward Vibrio species tested (V. harveyi, V. nereis, V. fluvialis, V. alginolyticus,

$V$. parahaemolyticus, $V$. vulnificus and $V$. anguillarum) ranging

from $<10 \mathrm{~mm}$ to $>30 \mathrm{~mm}$ inhibition zones

- Suggested the ability of the siderophore-producing

Streptomyces strains controlled the Vibrio pathogens by

competing for iron in the marine environment

- Attenuated the biofilm formation of $V$. harveyi with inhibition rate of 99.3\% at $2.5 \%(\mathrm{v} / \mathrm{v})$

- Dispersed the mature biofilm of $V$. harveyi with degradation rate of $75.6 \%$ at $2.5 \%(\mathrm{v} / \mathrm{v})$

- Suggested the anti-biofilm activity demonstrated by

Streptomyces A66 through the degradation of the

quorum-sensing factor N-AHSL ( $N$-acylated homoserine lactone)

- Produced guadinomine B, a type III secretion system inhibitor of Gram-negative bacteria, including Vibrio sp., with $\mathrm{IC}_{50}$ at $14 \mathrm{nM}$

- Administrated intramuscularly ethyl acetate extract of the secondary metabolite reduced the white spot syndrome virus load significantly (85\%) in the Fenneropenaeus indicus after third day of injection

You et al., 2005

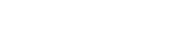




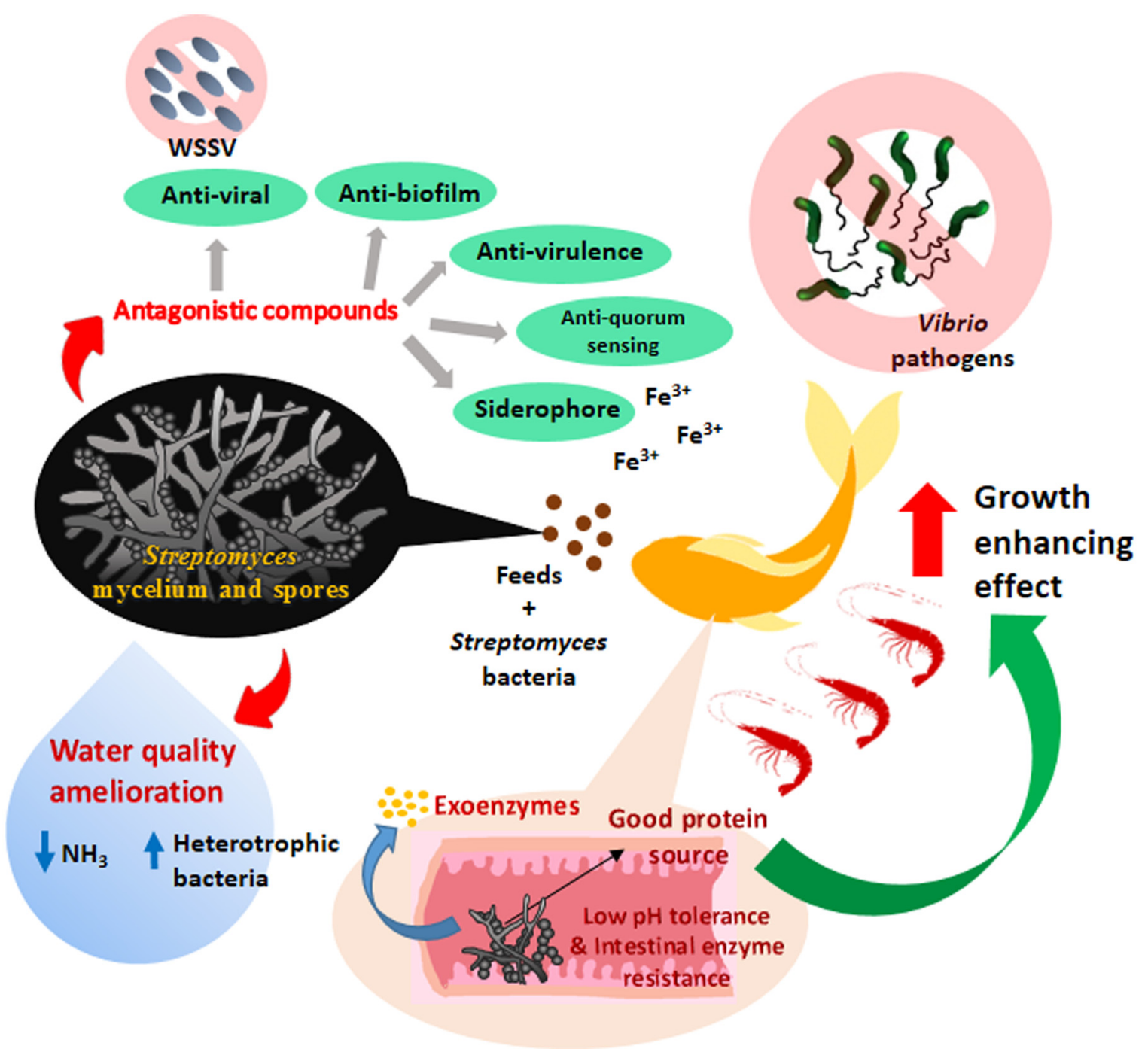

FIGURE 1 | The mechanism of action of probiotic effects of Streptomyces bacteria and their applications in aquaculture. The Streptomyces as probiotic in aquaculture could protect the livestock from pathogens through the production of various antagonistic compounds (e.g., anti-biofilm, anti-quorum sensing and anti-virulence) against Vibrio pathogens. Streptomyces probiotics attenuate the growth of pathogens by producing siderophores which reduce the bioavailability of iron $\left(\mathrm{Fe}^{3+}\right)$ for the pathogens in the aquatic environment. Anti-viral compounds are also produced by Streptomyces probiotic to prevent viral infection caused by white spot syndrome virus (WSSV) in aquaculture. Besides, the Streptomyces probiotics also play a role in ameliorating the water quality of aquaculture. Streptomyces probiotics help to regulate the microflora, especially to increase the protein mineralizing and ammonifying bacterial populations which accelerate the decomposition process of wastes materials and also ameliorate the water quality by reducing the ammonia level $\left(\mathrm{NH}_{3}\right)$. The consumption of feeds incorporated with the low pH tolerance and intestinal enzymes resistance Streptomyces probiotics could enhance the growth performance of the livestock by providing good protein sources. Streptomyces probiotics exhibit the ability to secrete hydrolytic exoenzymes which improve the amylolytic and proteolytic activity in the digestive tract of the livestock for more efficient use of the feed; eventually contribute to better growth performance of the livestock.

and resulting in growth attenuation of the pathogens as iron is essential for growth as well as biofilm formation (Weinberg, 2004). In addition, Streptomyces was also evidenced in the production of inhibitory compounds and metabolites involved in the attenuation of biofilm formation, anti-quorum sensing activity (You et al., 2007) and anti-virulence activity in Vibrio sp. (Iwatsuki et al., 2008). Besides displaying inhibitory effect on bacterial pathogens in aquaculture, Streptomyces also has been report to exhibit anti-viral activity, specifically against the white-spot syndrome virus (WSSV; Jenifer et al., 2015).
Streptomyces is primarily saprophytic, living in diverse soil habitats with the development of branching hyphal filaments under conducive environment (Flardh and Buttner, 2009). This unique growth adaptation allows Streptomyces in colonization of the solid substrates by adhering and penetrating to gain access on insoluble organic materials in the soil (Flardh and Buttner, 2009). Different hydrolytic enzymes such as amylase, protease and lipase can be produced by Streptomyces to break down the insoluble organic materials to provide nutrients for the formation of densely packed substrate mycelium which 
is reused to fuel the reproductive phase of aerial growth in producing chains of spores (Chater et al., 2010). These unique physiological adaptations of Streptomyces are believed to make them as potential probiotics such as the secretion of exoenzymes which may be helpful in facilitating the feed utilization and digestion once they colonize the host intestine in aquaculture. Das et al. (2010) demonstrated that the feed incorporated with Streptomyces increased the weight of Penaeus monodon shrimp, suggesting that these Streptomyces sp. secreted hydrolytic exoenzymes to improve the amylolytic and proteolytic activity in the shrimp digestive tract for more efficient use of the feed. The feed supplemented with Streptomyces fradiae isolated from mangrove sediment was also shown to enhance the growth of the post-larval P. monodon (Aftabuddin et al., 2013). Besides showing good growth promoting effects in shrimp, all the feeds supplemented with Streptomyces was also shown to improve growth performance of the ornamental fish, Xiphophorus helleri (red swordtail fish) after 50 days of feeding trial when compared to control without the Streptomyces sp. (Dharmaraj and Dhevendaran, 2010). Furthermore, the similar study also showed that the production of growth-promoting hormone, indoleacetic acid by the Streptomyces sp. could be contributed to the better growth rate as demonstrated by Xiphophorus helleri fed with Streptomyces supplemented feeds (Dharmaraj and Dhevendaran, 2010).

The formation of enzymatic digestion, sonic vibration and desiccation-resistant spores demonstrated by Streptomyces are also some of the attractive features for this genus of bacteria to resist the harsh environment conditions (McBride and Ensign, 1987), thereby allowing them to retain longer shelf life in the aquaculture ponds before being taken up or to resist the low $\mathrm{pH}$ in the gastrointestinal tracts of the animals. However, it should be noted that Streptomyces spore is only resistant to moderately high temperature (McBride and Ensign, 1987) as compared to the highly heat resistant endospores of Bacillus sp. which is compositionally and physiologically different from the Streptomyces spore. Nevertheless, Latha et al. (2015) reported that the Streptomyces sp. isolated from fecal sample of chicken showed excellent viability at $\mathrm{pH} \mathrm{2,} \mathrm{exhibited} \mathrm{strong} \mathrm{pepsin}$ resistance (at $3 \mathrm{mg} / \mathrm{mL}$ ) as well as the resistance toward both bile (at $0.3 \%$ ) and pancreatin (at $1 \mathrm{mg} / \mathrm{mL}$ ), suggesting that strains from the animal internal cavities would be better in adapting and colonizing the gastrointestinal of the animals. This is also demonstrated by Das et al. (2010) which isolated Streptomyces sp. from the sediment of the shrimp culture system able to reach the digestive system of the shrimp, hence allow easier establishment and growth of the probionts in the host. These findings indicate that the spore-forming capacity of Streptomyces with high acidity and bile acids tolerance makes them a more practical alternative than those bacteria with non-spore forming capability and further ascertain the potential of Streptomyces as probiotic in aquaculture (Das et al., 2010).

The in vivo challenge experiment conducted further proved that Streptomyces should be spotlighted as probiotics in aquaculture (Das et al., 2010). This study successfully demonstrated the protection effect of Streptomyces on both juvenile and adult Artemia (15 days old) from Vibrio pathogens. The study showed that the Streptomyces at $1 \%$ concentration $(\mathrm{v} / \mathrm{v})$ resulted in higher survival rates than the untreated control group of Artemia after challenged with $V$. harveyi or $V$. proteolyticus at $10^{6} \mathrm{CFU} / \mathrm{mL}$. The protective response shown by the study suggests that Streptomyces could be administrated to target organisms through bioencapsulation in Artemia as a vector for supplementing the beneficial Streptomyces probiotics in aquaculture. Bioencapsulation of probiotics in live food such as Artemia and rotifers was demonstrated to be more effective in delivery of the probiotics to the digestive tract of the target aquaculture organisms by previous studies (Gatesoupe, 2002; Suzer et al., 2008). The study also further evaluated the efficacy of the Streptomyces in protecting the shrimp P. monodon from the Vibrio pathogens. The feed supplemented with Streptomyces sp. CLS-28 for 15 days was found to be exerting protection effect on shrimp $P$. monodon against the $12 \mathrm{~h}$ challenge of $V$. harveyi $\left(\mathrm{LD}_{50}\right.$ at $10^{6.5} \mathrm{CFU} / \mathrm{mL}$; Das et al., 2010). A more recent study reported a marine $S$. rubrolavendulae M56 (accession number KJ403746) was shown to exhibit antagonistic activity against all four Vibrio sp. including $V$. harveyi, $V$. alginolyticus, $V$. parahaemolyticus and $V$. fluvialis in an in vitro co-culture experiment (Augustine et al., 2015). In order to confirm the in vitro findings, Augustine et al. (2015) demonstrated that the biogranules S. rubrolavendulae M56 resulted in lower percentage of mortality of $P$. monodon post-larvae with the reduction of viable Vibrio sp. in the culture system after 28 days.

The build-up of ammonia and nitrite level is a major water quality problem which has considerable effects on the health status of the aquaculture livestock due the accumulation of metabolic waste of cultured organisms and the decomposition of the residual feed. The probiotic Streptomyces was also found to regulate the microflora of the aquaculture water besides controlling the pathogenic microorganisms and resulted in a better pond conditions. Literature showed that the application of probiotic product did not adversely affect the microflora of aquaculture in turn increased the protein mineralizing and ammonifying bacterial population which help to accelerate the decomposition process of the accumulated wastes materials (Devaraja et al., 2002). Several studies also demonstrated similar results indicating the reduction of ammonia level and increased in the total heterotrophic bacteria in the ponds/tanks treated with the probiotic Streptomyces as compared to the control ponds/tanks (Das et al., 2006, 2010; Aftabuddin et al., 2013). These findings suggested that Streptomyces could be applied as probiotics which ameliorate the water quality of aquaculture indirectly improve the growth performance and yield of the cultured organisms.

Traditionally, fish meal has been an indispensable ingredient in commercial aquaculture feeds due to its high protein content with excellent amino acid profile and is highly digestible (Gatlin et al., 2007). However, current feed formulations have shifted to other alternative protein source due to the high cost and limited availability of fish meal. Microbial single cell protein of 
Streptomyces is one of the alternative sources of protein and has been utilized and evaluated for better food conversion efficiency and growth for fish (Suguna, 2012; Selvakumar et al., 2013) and shrimp (Manju and Dhevendaran, 1997). Dharmaraj and Dhevendaran (2010) suggested that the use of Streptomyces not only showing beneficial effects as probiotic in aquaculture, the incorporation of Streptomyces in the feed is also a cost effective approach as the probiotic bacteria replaced around 30-40\% of the fish meal used in a feed. The study demonstrated that Streptomyces can be a cheaper alternative protein source in the aquaculture feed (Dharmaraj and Dhevendaran, 2010).

\section{LIMITATIONS OF STREPTOMYCES AS PROBIOTIC IN AQUACULTURE}

Geosmin and MIB (2-methylisoborneol) are two common semivolatile terpenoid compounds that exhibit earthy/musty taste and odor produced by Streptomyces have been known to reduce the palatability of the cultured livestock and negative impact for aquaculture industries (Auffret et al., 2011). These off-flavor compounds are known to be absorbed and bioaccumulated in the gills, skin and flesh of fish up to 200- to 400 -folds as compared to the ambient concentration, resulting in lower commercial value of the fish (Howgate, 2004). Many efforts have been shown in literatures for the removal of these earthy odor compounds from water involving the use of powdered activated carbon, ozonation and biofiltration (Elhadi et al., 2004). Among these technologies, ozonation is suggested to effective in this case with the use of Streptomyces as the probiotics in aquaculture. Ozone has been known to remove odorants such as geosmin and MIB from water via oxidation (Gonçalves and Gagnon, 2011). A study has demonstrated that the combined effect of ozonation (at $0.3 \mathrm{mg} \mathrm{O} / \mathrm{L} \mathrm{ROC)} \mathrm{and} \mathrm{probiotic} \mathrm{diets}$ (Bacillus sp. S11) was able to protect shrimp P. monodon from Vibrio challenge test without harming shrimp and the probiotic bacteria in the internal system of shrimp (Meunpol et al., 2003).

Furthermore, the risk of lateral gene transfer of antibiotic resistance genes could be an argument against the use of Streptomyces as probiotic in aquaculture. Despite that, there are increasing reports on the antibiotic resistance developed by most of the commonly used probiotics such as Lactobacillus sp. (Sharma et al., 2015), Bifidobacterium sp. and Bacillus sp. (Gueimonde et al., 2013). Furthermore, studies also reported that the antibiotic resistance phenotypes displayed by the probiotic Streptomyces strains were generally conferred by their intrinsic resistance properties (Das et al., 2010; Latha et al., 2015). Hence,

\section{REFERENCES}

Aftabuddin, S., Kashem, M. A., Kader, M. A., Sikder, M. N. A., and Hakim, M. A. (2013). Use of Streptomyces fradiae and Bacillus megaterium as probiotics in the experimental culture of tiger shrimp Penaeus monodon (Crustacea, Penaeidae). AACL Bioflux 6, 253-267.

Ahmed, E., and Holmstrom, S. J. (2014). Siderophores in environmental research: roles and applications. Microb. Biotechnol. 7, 196-208. doi: 10.1111/17517915.12117 systematic screening for potential antibiotic resistance gene determinants in potential probiotics genome has to be conducted to assess the potential risks and mobility. Furthermore, curative strategies can be valuable tool to remove the genetic element that harbor antibiotic resistance from the relevant probiotic strains (Morelli and Campominosi, 2002; Rosander et al., 2008). For instance, Rosander et al. (2008) successfully demonstrated the protoplast formation curing method able to remove two resistant plasmids from the parent Lactobacillus reuteri (ATCC 55730) and without affecting the probiotic properties of the strain. All in all, Streptomyces can be one of the interesting probiotics to be further exploited as an alternative to antibiotics in maintaining a sustainable aquaculture.

\section{CONCLUSION AND FUTURE WORK}

To date, the number of study employs Streptomyces as probiotics in aquaculture is still limited although promising results have been represented by previous studies. A schematic figure is also illustrated to show the mechanism of action of the probiotic effects demonstrated by the Streptomyces in aquaculture (Figure 1). In order for Streptomyces being included among the commonly used biological control agents in aquaculture, further extensive trials are still required to establish the probiotic nature of Streptomyces in disease prevention and growth enhancement of aquaculture animals. Furthermore, a better understanding is needed on the exact mode of action of Streptomyces involved in probiotic effects. Hence, further research could focus more on molecular techniques to elucidate the possible underlying mechanism portrayed by Streptomyces probiotic in aquaculture settings.

\section{AUTHOR CONTRIBUTIONS}

All authors listed, have made substantial, direct and intellectual contribution to the work, and approved it for publication.

\section{ACKNOWLEDGMENTS}

This work was supported by the Monash University Malaysia ECR Grant (5140077-000-00), MOSTI eScience Funds (02-0210-SF0215 and 06-02-10-SF0300), University of Malaya for High Impact Research Grant (UM-MOHE HIR Nature Microbiome Grant No. H-50001-A000027 and No. A000001-50001).

Auffret, M., Pilote, A., Proulx, E., Proulx, D., Vandenberg, G., and Villemur, R. (2011). Establishment of a real-time PCR method for quantification of geosminproducing Streptomyces spp. in recirculating aquaculture systems. Water Res. 45, 6753-6762. doi: 10.1016/j.watres.2011.10.020

Augustine, D., Jacob, J. C., and Philip, R. (2015). Exclusion of Vibrio spp. by an antagonistic marine actinomycete Streptomyces rubrolavendulae M56. Aquac. Res. 1-10. doi: 10.1111/are.12746

Bondad-Reantaso, M. G., Subasinghe, R. P., Arthur, J. R., Ogawa, K., Chinabut, S., Adlard, R., et al. (2005). Disease and health management in 
Asian aquaculture. Vet. Parasitol. 132, 249-272. doi: 10.1016/j.vetpar.2005. 07.005

Butler, M. S. (2008). Natural products to drugs: natural product-derived compounds in clinical trials. Nat. Prod. Rep. 25, 475-516. doi: 10.1039/b51 $4294 \mathrm{f}$

Chater, K. F., Biro, S., Lee, K. J., Palmer, T., and Schrempf, H. (2010). The complex extracellular biology of Streptomyces. FEMS Microbiol. Rev. 34, 171-198. doi: 10.1111/j.1574-6976.2009.00206.x

Chen, H., Liu, S., Xu, X. R., Liu, S. S., Zhou, G. J., Sun, K. F., et al. (2015). Antibiotics in typical marine aquaculture farms surrounding Hailing Island, South China: occurrence, bioaccumulation and human dietary exposure. Mar. Pollut. Bull. 90, 181-187. doi: 10.1016/j.marpolbul.2014. 10.053

Das, S., Lyla, P., and Ajmal Khan, S. (2006). Application of Streptomyces as a probiotic in the laboratory culture of Penaeus monodon (Fabricius). Isr. J. Aquac. 58, 198-204.

Das, S., Ward, L. R., and Burke, C. (2010). Screening of marine Streptomyces spp. for potential use as probiotics in aquaculture. Aquaculture 305, 32-41. doi: 10.1016/j.aquaculture.2010.04.001

Defoirdt, T., Boon, N., Sorgeloos, P., Verstraete, W., and Bossier, P. (2007). Alternatives to antibiotics to control bacterial infections: luminescent vibriosis in aquaculture as an example. Trends Biotechnol. 25, 472-479. doi: 10.1016/j.tibtech.2007.08.001

Desriac, F., Defer, D., Bourgougnon, N., Brillet, B., Le Chevalier, P., and Fleury, Y. (2010). Bacteriocin as weapons in the marine animal-associated bacteria warfare: inventory and potential applications as an aquaculture probiotic. Mar. Drugs 8, 1153-1177. doi: 10.3390/md8041153

Devaraja, T. N., Yusoff, F. M., and Shariff, M. (2002). Changes in bacterial populations and shrimp production in ponds treated with commercial microbial products. Aquaculture 206, 245-256. doi: 10.1016/s0044-84 86(01)00721-9

Dharmaraj, S., and Dhevendaran, K. (2010). Evaluation of Streptomyces as a probiotic feed for the growth of ornamental fish Xiphophorus helleri. Food Technol. Biotechnol. 48, 497-504.

Elhadi, S. L., Huck, P. M., and Slawson, R. M. (2004). Removal of geosmin and 2-methylisoborneol by biological filtration. Water Sci. Technol. 49, 273-280.

FAO (2014). The State of World Fisheries and Aquaculture 2014. Rome: Food and Agriculture Organization.

Flardh, K., and Buttner, M. J. (2009). Streptomyces morphogenetics: dissecting differentiation in a filamentous bacterium. Nat. Rev. Microbiol. 7, 36-49. doi: $10.1038 /$ nrmicro 1968

Flegel, T. W. (2012). Historic emergence, impact and current status of shrimp pathogens in Asia. J. Invertebr. Pathol. 110, 166-173. doi: 10.1016/j.jip.2012.03.004

Fleming, A. (1944). The discovery of penicillin. Br. Med. Bull. 2, 4-5.

Fuller, R. (1989). Probiotics in man and animals: a review. J. Appl. Bacteriol. 66, 365-378. doi: 10.1111/j.1365-2672.1989.tb05105.x

Gatesoupe, F.-J. (2002). Probiotic and formaldehyde treatments of Artemia nauplii as food for larval pollack, Pollachius pollachius. Aquaculture 212, 347-360. doi: 10.1016/s0044-8486(02)00138-2

Gatlin, D. M., Barrows, F. T., Brown, P., Dabrowski, K., Gaylord, T. G., Hardy, R. W., et al. (2007). Expanding the utilization of sustainable plant products in aquafeeds: a review. Aquac. Res. 38, 551-579. doi: 10.1111/j.13652109.2007.01704.x

Gonçalves, A. A., and Gagnon, G. A. (2011). Ozone application in recirculating aquaculture system: an overview. Ozone Sci. Eng. 33, 345-367. doi: 10.1080/01919512.2011.604595

Gueimonde, M., Sanchez, B., de Los Reyes-Gavilán, C.G., and Margolles, A. (2013). Antibiotic resistance in probiotic bacteria. Front. Microbiol. 4:202. doi: $10.3389 /$ fmicb. 2013.00202

Hai, N. (2015). The use of probiotics in aquaculture. J. Appl. Microbiol. 119, 917-935. doi: 10.1111/jam.12886

Howgate, P. (2004). Tainting of farmed fish by geosmin and 2-methyl-iso-borneol: a review of sensory aspects and of uptake/depuration. Aquaculture 234, 155-181. doi: 10.1016/j.aquaculture.2003.09.032

Huang, Y., Zhang, L., Tiu, L., and Wang, H. H. (2015). Characterization of antibiotic resistance in commensal bacteria from an aquaculture ecosystem. Front. Microbiol. 6:914. doi: 10.3389/fmicb.2015.00914
Iwatsuki, M., Uchida, R., Yoshijima, H., Ui, H., Shiomi, K., Kim, Y.-P., et al. (2008). Guadinomines, type III secretion system inhibitors, produced by Streptomyces sp. K01-0509. J. Antibiot. (Tokyo) 61, 230-236. doi: 10.1038/ja.2008.33

Jenifer, J. S., Donio, M. B., Michaelbabu, M., Vincent, S. G., and Citarasu, T. (2015). Haloalkaliphilic Streptomyces spp. AJ8 isolated from solar salt works and its' pharmacological potential. AMB Express 5, 143. doi: 10.1186/s13568-0150143-2

Lalloo, R., Moonsamy, G., Ramchuran, S., Görgens, J., and Gardiner, N. (2010). Competitive exclusion as a mode of action of a novel Bacillus cereus aquaculture biological agent. Lett. Appl. Microbiol. 50, 563-570. doi: 10.1111/j.1472765x.2010.02829.x

Latha, S., Vinothini, G., John Dickson, D.C., and Dhanasekaran, D. (2015). In vitro probiotic profile based selection of indigenous actinobacterial probiont Streptomyces sp. JD9 for enhanced broiler production. J. Biosci. Bioeng. 121, 124-131. doi: 10.1016/j.jbiosc.2015.04.019

Lee, L.-H., Zainal, N., Azman, A.-S., Eng, S.-K., Ab Mutalib, N.-S., Yin, W.F., et al. (2014a). Streptomyces pluripotens sp. nov., a bacteriocin-producing streptomycete that inhibits meticillin-resistant Staphylococcus aureus. Int. J. Syst. Evol. Microbiol. 64, 3297-3306. doi: 10.1099/ijs.0.065045-0

Lee, L.-H., Zainal, N., Azman, A. S., Eng, S. K., Goh, B.-H., Yin, W.-F., et al. (2014b). Diversity and antimicrobial activities of actinobacteria isolated from tropical mangrove sediments in Malaysia. ScientificWorldJournal 2014, 698178. doi: $10.1155 / 2014 / 698178$

Letchumanan, V., Chan, K.-G., and Lee, L.-H. (2014). Vibrio parahaemolyticus: a review on the pathogenesis, prevalence, and advance molecular identification techniques. Front. Microbiol. 5:705. doi: 10.3389/fmicb.2014.00705

Letchumanan, V., Chan, K.-G., and Lee, L.-H. (2015a). An insight of traditional plasmid curing in Vibrio species. Front. Microbiol. 6:735. doi: 10.3389/fmicb.2015.00735

Letchumanan, V., Pusparajah, P., Tan, L. T.-H., Yin, W.-F., Lee, L.-H., and Chan, K.-G. (2015b). Occurrence and antibiotic resistance of Vibrio parahaemolyticus from shellfish in Selangor, Malaysia. Front. Microbiol. 6:1417. doi: 10.3389/fmicb.2015.01417

Letchumanan, V., Yin, W.-F., Lee, L.-H., and Chan, K.-G. (2015c). Prevalence and antimicrobial susceptibility of Vibrio parahaemolyticus isolated from retail shrimps in Malaysia. Front. Microbiol. 6:33. doi: 10.3389/fmicb.2015.00033

Lightner, D. V., Redman, R. M., Pantoja, C. R., Tang, K. F., Noble, B. L., Schofield, P., et al. (2012). Historic emergence, impact and current status of shrimp pathogens in the Americas. J. Invertebr. Pathol. 110, 174-183. doi: 10.1016/j.jip.2012.03.006

Manivasagan, P., Venkatesan, J., Sivakumar, K., and Kim, S. K. (2013). Marine actinobacterial metabolites: current status and future perspectives. Microbiol. Res. 168, 311-332. doi: 10.1016/j.micres.2013.02.002

Manju, K., and Dhevendaran, K. (1997). Effect of bacteria and actinomycetes as single cell protein feed on growth of juveniles of Macrobrachium idella (Hilgendorf). Indian J. Exp. Biol. 35, 53-55.

Marshall, B. M., and Levy, S. B. (2011). Food animals and antimicrobials: impacts on human health. Clin. Microbiol. Rev. 24, 718-733. doi: 10.1128/CMR.00 002-11

Martínez Cruz, P., Ibáñez, A. L., Monroy Hermosillo, O. A., and Ramírez Saad, H. C. (2012). Use of probiotics in aquaculture. ISRN Microbiol. 2012, 916845. doi: 10.5402/2012/916845

Mathieson, A. (2012). The State of World Fisheries and Aquaculture. Rome: FAO Fisheries and Aquaculture Department.

McBride, M. J., and Ensign, J. C. (1987). Effects of intracellular trehalose content on Streptomyces griseus spores. J. Bacteriol. 169, 4995-5001.

Meunpol, O., Lopinyosiri, K., and Menasveta, P. (2003). The effects of ozone and probiotics on the survival of black tiger shrimp (Penaeus monodon). Aquaculture 220, 437-448. doi: 10.1016/s0044-8486(02)00586-0

Moffitt, C. M., and Cajas-Cano, L. (2014). Blue growth: the 2014 FAO state of world fisheries and aquaculture. Fisheries 39, 552-553. doi: $10.1080 / 03632415.2014 .966265$

Morelli, L., and Campominosi, E. (2002). Genetic stability of Lactobacillus paracasei subsp. paracasei F19. Microb. Ecol. Health Dis. 14, 14-16. doi: 10.3402/mehd.v14i1.8206

Newaj-Fyzul, A., Al-Harbi, A., and Austin, B. (2014). Review: developments in the use of probiotics for disease control in aquaculture. Aquaculture 431, 1-11. doi: 10.1016/j.aquaculture.2013.08.026 
Ouwehand, A., Salminen, S., and Isolauri, E. (2002). "Probiotics: an overview of beneficial effects," in Lactic Acid Bacteria: Genetics, Metabolism and Applications, eds R. J. Siezen, J. Kok, T. Abee, and G. Schasfsma (Dordrecht: Springer Netherlands), 279-289. doi: 10.1007/978-94-017-2029-8_18

Parker, R. (1974). Probiotics, the other half of the antibiotic story. Anim. Nutr. Health 29, 4-8.

Pereira, A. M., Silva, L. J., Meisel, L. M., and Pena, A. (2015). Fluoroquinolones and tetracycline antibiotics in a portuguese aquaculture system and aquatic surroundings: occurrence and environmental impact. J. Toxicol. Environ. Health A 78, 959-975. doi: 10.1080/15287394.2015.1036185

Pham, D. K., Chu, J., Do, N. T., Brose, F., Degand, G., Delahaut, P., et al. (2015). Monitoring antibiotic use and residue in freshwater aquaculture for domestic use in Vietnam. Ecohealth 12, 480-489. doi: 10.1007/s10393-01 4-1006-z

Rosander, A., Connolly, E., and Roos, S. (2008). Removal of antibiotic resistance gene-carrying plasmids from Lactobacillus reuteri ATCC 55730 and characterization of the resulting daughter strain, L. reuteri DSM 17938. Appl. Environ. Microbiol. 74, 6032-6040. doi: 10.1128/AEM.00991-08

Salamoura, C., Kontogianni, A., Katsipi, D., Kandylis, P., and Varzakas, T. (2014). Probiotic fermented milks made of cow's milk, goat's milk and their mixture. J. Biotechnol. 185S, S125. doi: 10.1016/j.jbiotec.2014.07.262

Selvakumar, D., Jyothi, P., and Dhevendaran, K. (2013). Application of Streptomyces as a single cell protein to the juvenile fish Xiphophorus maculatus. World J. Fish Mar. Sci. 5, 582-586. doi: 10.5829/idosi.wjfms.2013.05.06. 74154

Ser, H.-L., Palanisamy, U. D., Yin, W.-F., Malek, A., Nurestri, S., Chan, K.-G., et al. (2015a). Presence of antioxidative agent, Pyrrolo [1, 2-a] pyrazine-1, 4dione, hexahydro-in newly isolated Streptomyces mangrovisoli sp. nov. Front. Microbiol. 6:854. doi: 10.3389/fmicb.2015.00854

Ser, H.-L., Ab Mutalib, N. S., Yin, W.-F., Chan, K.-G., Goh, B.-H., and Lee, L.-H. (2015b). Evaluation of antioxidative and cytotoxic activities of Streptomyces pluripotens MUSC 137 isolated from mangrove soil in Malaysia. Front. Microbiol. 6:1398. doi: 10.3389/fmicb.2015.01398

Sharma, P., Tomar, S. K., Sangwan, V., Goswami, P., and Singh, R. (2015). Antibiotic resistance of Lactobacillus sp. isolated from commercial probiotic preparations. J. Food Saf. 36, 38-51. doi: 10.1111/jfs.12211

Shruti, C. (2012). Vibrio related diseases in aquaculture and development of rapid and accurate identification methods. J. Marine Sci. Res. Dev. S1, 002. doi: 10.4172/2155-9910.s1-002

Sugita, H., Matsuo, N., Hirose, Y., Iwato, M., and Deguchi, Y. (1997). Vibrio sp. strain NM 10, isolated from the intestine of a Japanese coastal fish, has an inhibitory effect against Pasteurella piscicida. Appl. Environ. Microbiol. 63, 4986-4989.

Sugita, H., Ohta, K., Kuruma, A., and Sagesaka, T. (2007). An antibacterial effect of Lactococcus lactis isolated from the intestinal tract of the Amur catfish, Silurus asotus Linnaeus. Aquac. Res. 38, 1002-1004. doi: 10.1111/j.13652109.2007.01765.x
Suguna, S. (2012). Production of probiotics from Streptomyces sp. associated with fresh water fish and its growth evaluation on Xiphorous helleri. Int. J. Pharm. Biol. Sci. Arch. 3, 601-603.

Suzer, C., Çoban, D., Kamaci, H. O., Saka, Ş., Firat, K., Otgucuoğlu, Ö, et al. (2008). Lactobacillus spp. bacteria as probiotics in gilthead sea bream (Sparus aurata, L.) larvae: effects on growth performance and digestive enzyme activities. Aquaculture 280, 140-145. doi: 10.1016/j.aquaculture.2008.04.020

Tan, L. T.-H., Ser, H.-L., Yin, W.-F., Chan, K.-G., Lee, L.-H., and Goh, B.-H. (2015). Investigation of antioxidative and anticancer potentials of Streptomyces sp. MUM256 isolated from Malaysia mangrove soil. Front. Microbiol. 6:1316. doi: $10.3389 /$ fmicb. 2015.01316

Tomova, A., Ivanova, L., Buschmann, A. H., Rioseco, M. L., Kalsi, R. K., Godfrey, H. P., et al. (2015). Antimicrobial resistance genes in marine bacteria and human uropathogenic Escherichia coli from a region of intensive aquaculture. Environ. Microbiol. Rep. 7, 803-809. doi: 10.1111/1758-2229. 12327

Verschuere, L., Rombaut, G., Sorgeloos, P., and Verstraete, W. (2000). Probiotic bacteria as biological control agents in aquaculture. Microbiol. Mol. Biol. Rev. 64, 655-671. doi: 10.1128/mmbr.64.4.655-671.2000

Wang, L., Chen, Y., Huang, H., Huang, Z., Chen, H., and Shao, Z. (2015). Isolation and identification of Vibrio campbellii as a bacterial pathogen for luminous vibriosis of Litopenaeus vannamei. Aquac. Res. 46, 395-404. doi: $10.1111 /$ are.12191

Weinberg, E. D. (2004). Suppression of bacterial biofilm formation by iron limitation. Med. Hypotheses 63, 863-865. doi: 10.1016/j.mehy.2004.04.010

Xiong, W., Sun, Y., Zhang, T., Ding, X., Li, Y., Wang, M., et al. (2015). Antibiotics, antibiotic resistance genes, and bacterial community composition in fresh water aquaculture environment in china. Microb. Ecol. 70, 425-432. doi: 10.1007/s00248-015-0583-x

You, J., Cao, L., Liu, G., Zhou, S., Tan, H., and Lin, Y. (2005). Isolation and characterization of actinomycetes antagonistic to pathogenic Vibrio spp. from nearshore marine sediments. World J. Microbiol. Biotechnol. 21, 679-682. doi: 10.1007/s11274-004-3851-3

You, J., Xue, X., Cao, L., Lu, X., Wang, J., Zhang, L., et al. (2007). Inhibition of Vibrio biofilm formation by a marine actinomycete strain A66. Appl. Microbiol. Biotechnol. 76, 1137-1144. doi: 10.1007/s00253-007-1074-x

Conflict of Interest Statement: The authors declare that the research was conducted in the absence of any commercial or financial relationships that could be construed as a potential conflict of interest.

Copyright (c) 2016 Tan, Chan, Lee and Goh. This is an open-access article distributed under the terms of the Creative Commons Attribution License (CC BY). The use, distribution or reproduction in other forums is permitted, provided the original author(s) or licensor are credited and that the original publication in this journal is cited, in accordance with accepted academic practice. No use, distribution or reproduction is permitted which does not comply with these terms. 